\title{
Schistosomes from the Persian Gulf: phylogenetic relationships, host associations and life-cycle elucidation of Ornithobilharzia canaliculata (Rudolphi, 1819) Odhner, 1912
}

Maral Khosravi ( $\sim$ khosravi.maral@gmail.com )

GEOMAR Helmholtz Centre for Ocean Research Kiel

David W. Thieltges

NIOZ Royal Netherlands Institute for Sea Research

Jebreil Shamseddin

Hormozgan University of Medical Sciences

Simona Georgieva

Bulgarian Academy of Sciences

\section{Research Article}

Keywords: Persian Gulf, Gulf of Oman, Avian schistosomes, Ornithobilharzia canaliculata, Austrobilharzia, Pirenella cingulata

Posted Date: March 22nd, 2022

DOI: https://doi.org/10.21203/rs.3.rs-1387572/v2

License: (1) This work is licensed under a Creative Commons Attribution 4.0 International License.

Read Full License 


\section{Abstract \\ Background}

Avian schistosomes comprise a diverse and widespread group of trematodes known for their surprising ability to switch into new hosts and habitats. Their cercariae are the causative agents of the waterborne allergic disease cercarial dermatitis. There are 13 recognised genera of avian schistosomes with majority of the extant species with freshwater-based life-cycles. Despite the considerable research attention on avian schistosomes much less it is known about the diversity, geographical range and host associations of the marine representatives. Here, we provide novel data on the species diversity and host-parasite relationships of the marine schistosomes in respect to their intermediate gastropod host from the Persian Gulf.

\section{Methods}

A total of 1,745 horn snails of Pirenella cingulata (Gmelin), were examined during a survey from December 2019 to February 2020 from eight distinct locations along the coast of Iran. Partial sequences of the mitochondrial cytochrome $c$ oxidase subunit $1(\operatorname{cox} 1)$ and the nuclear 28S rRNA gene were generated for the schistosome isolates recovered and used for molecular identification and phylogenetic reconstruction.

\section{Results}

Our molecular analyses inferred from both molecular markers revealed presence of two schistosome species, Ornithobilharzia canaliculata (Rudolphi, 1819) Odhner, 1912 and a putative new species of Austrobilharzia Johnston, 1917. Molecular elucidation of the life-cycle of $O$. canaliculata was achieved for the first time via matching novel and published sequence data from adult and larval stages. This is the first record of Ornithobilharzia from the Persian Gulf and globally the first record of this genus in a potamidid snail host.

\section{Conclusions}

The present study provides new host and distribution records for major etiological agents of cercarial dermatitis and contributes important information on host-parasite relationships. Our study further highlights the importance of the molecular systematics in the assessment of schistosome diversity and calls for further surveys in order to reach a better understanding of the schistosome diversity and patterns of relationships among them, host associations, transmission strategies and distribution coverage.

\section{Background}


Avian schistosomes comprise a diverse and widespread group known for their surprising ability to switch into new hosts and habitats [1]. Their cercariae are recognised as important causative agents of the waterborne allergic disease cercarial dermatitis ([2] and references therein). However, the current systematics and taxonomy of the group is exclusively based on morphological characters of the adults and species delimitation and difficulties in the identification of their larval stages hindered the assessment of their diversity, host and distributional ranges [3]. Often larval and adult stages from natural infections in snails and birds have been assigned to belong to the same species with the lack of further evidence linking their conspecificity. The discovery of avian schistosome diversity, their life-cycle elucidations and taxonomy has largely benefited from molecular phylogenetics studies $([2,4]$ and references therein). To date, a total of 13 genera of avian schistosomes with about 70 species and 20 species-level genetically distinct lineages are known around the globe $[4,5]$. Based on the habitat where their life-cycles take place, avian schistosomes consist of freshwater and marine representatives.

Marine schistosomes represent a small group of widely distributed digeneans that are parasitic as adults in the vascular systems of various birds [6]. Predominant part of the extant marine schistosomes is known to parasitise charadriiforms (gulls and/or terns) with a few records in spheniscids [5, 6]. Currently, four genera, Austrobilharzia Johnston, 1917, Gigantobilharzia Odhner, 1910, Marinabilharzia Lorenti, Brant, Gilardoni, Díaz \& Cremonte, 2022 and Ornithobilharzia Odhner, 1912 are known to have marinebased life-cycles [4, 5]. Of these, Ornithobilharzia Odhner, 1912 and Austrobilharzia Johnston, 1917 were recognised as an earlier diverging group which gave rise to all existent schistosomes [9]. Although, schistosomes represent a well-circumscribed monophyletic group, monophyly for the avian representatives has been rejected [4, 9]. Phylogenetic hypotheses, revealed a basal switch from marine to freshwater environment which has occurred along a switch from caenogastropod to heterobranch snails [1]. A secondary swish from freshwater to marine environment has been suggested to have occurred with colonisation of heterobranch snails from the families Haminoeidae Pilsbry, 1895 and Siphonariidae Gray, 1827 [10-12].

Ornithobilharzia canaliculata was first described by Rudolphi (1819) as Distoma canaliculatum, the first schistosome species reported from the intestine of terns ("Sternae species brasilianae") in Brazil [13]. In 1912, Odhner [14] erected the genus Ornithobilharzia and defined D. canaliculatum as the type-species. Despite the wide range of known definitive hosts including marine birds of six genera (Larus L., Sterna L., Chlidonias Rafinesque, Hydroprogne Kaup, Puffinus (Manxsherwater), and Thalasseus F. Boie) and a wide geographical range across the Holarctic and Neotropics [15] only a single marine gastropod species, Lampanella minima (Gmelin), has been assigned as the intermediate host in the Gulf of Mexico [16]. However, experimental elucidation of the life-cycle has never been carried out and a formal description of the cercaria of $O$. canaliculata is still lacking. Under the current taxonomic treatment, the genus includes three species: O. amplitesta Gubanov \& Mamaev in Mamaev, 1959; O. canaliculata (Rudolphi, 1819) Odhner, 1912; and O. lari McLeod, 1937.

The closely-related genus Austrobilharzia Johnston, 1917 currently comprises 4 species: $A$. odhneri (Faust, 1924) Farely, 1971; A. penneri Short \& Holliman, 1961; A. terrigalensis Johnston, 1917; A. 
variglandis (Miller \& Northup, 1926) Penner 1953. The genus was erected by Johnston (1917) to accommodate $A$. terrigalensis, a species found in the intestine of Larus novae-hollandiae shot at Terrigal, New South Wales, Australia. Caenogastropod snails have been reported as the natural intermediate hosts [17-20]. However, a combination of identification and taxonomic problems, have led to the biological paradox of a single species, $A$. terrigalensis, occurring at three distinct geographical regions and utilising different species of caenogastropod and bird hosts. Based on the geographical distribution, $A$. terrigalensis was assumed to occur in Larus novae-hollandiae and Batillaria australis in Australia; $A$. valisineria, Mergus serrator L., Aythya affinis Eyton, 1838 and Ilyanassa obsoleta (Say) in North America; and Arenaria interpres (L.) and Littorina pintado (W. Wood, 1828) in the Pacific.

Caenogastropods are one of the most diverse groups of gastropods comprising about $60 \%$ of the known species with predominantly marine forms [21] and are known as intermediate hosts for a variety of trematode parasites $[17,22,23]$. Members of the genus Pirenella J. E. Gray are abundant inhabitants of intertidal sedimentary shores with wide geographical distribution ranging from the western Pacific and Indian Ocean to the eastern Mediterranean Sea. A recent study reported a total of 16 valid species within the genus, with some species known as inhabitants of extreme environments, from brackish estuaries to hypersaline lagoons and inland lakes [24]. Pirenella cingulata (Gmelin, 1791) is the most abundant caenogastropod species in the Persian and Oman Gulfs. It is known for its tolerance to environmental extremes and ability to flourish in intertidal muddy-sandy and mudflats adjacent to mangrove forests [25, 26].

As part of an ongoing study aiming to characterise trematode diversity in the horn snail Pirenella cingulata along the coast of Iran, we here report on the diversity of avian schistosomes associated with marine life-cycles using $\operatorname{cox} 1$ and $28 \mathrm{~S}$ rDNA sequence data. The present study is the first to molecularly elucidate the life-cycle of the first ever described schistosome, 0 . canaliculata and further reports on a putative new species of Austrobilharzia. Both species recovered are of the largely understudied marine schistosomes known for their implication as causative agents of cercarial dermatitis. This is the first unambiguous documentation that the potamidid snail $P$. cingulata is the natural snail host for $O$. canaliculata. The evolutionary relationships and host-parasite associations among the avian schistosomes are further revisited.

\section{Materials And Methods}

\section{Host and parasite collection}

A total of 1,745 adult P. cingulata (Gmelin, 1791) were sampled from 9 distinct locations along the Iranian coastline between December 2019 and February 2020 (Fig. 1). Samples comprised a minimum of 200 individual snails per locality which were opportunistically collected by hand at the low tide from the intertidal zone. Snails were transferred alive to the laboratory, where they were measured (length and weigh) and labelled with a unique code given to each specimen. Each snail was then placed in an individual $50 \mathrm{ml}$ beaker filled with filtered seawater and exposed to a warm light source for 3-4 hours to 
simulate cercarial emergence. Beakers were screened under a stereomicroscope for the presence of cercariae indicating patent infections in the snail host. Prepatent infections were detected with snail dissections which were conducted on the $3^{\text {rd }}$ day of light stimulation. Both, the released cercariae and schistosome sporocysts recovered from the host's tissue were washed with distilled water and preserved in molecular grade ethanol for DNA isolation and sequencing.

\section{Sequence generation}

Ethanol-preserved samples of pooled cercariae were subjected to DNA extraction and sequencing. Partial cox1 and 28S rDNA sequences were generated for the schistosome parasites recovered in order to achieve molecular identification and carry out reconstruction of their evolutionary relationships using published primers (28S (digl2 + 1500R [27, 28]; ECD2+900F [29, 30] as internal sequencing primers; cox1: JB3+JB4.5 [31] or C01-R [32]). Contiguous sequences were aligned with MAFFT v.7 [33, 34] as an online execution. After alignment, sequences for cox 1 were checked for stop codons using the echinoderm and flatworm mitochondrial code (translation table 9;[35]). All sequences were trimmed in order the first base to correspond to the first codon position in order to simplify position-coding in the downstream analyses.

\section{Phylogenetic analyses}

Phylogenetic analyses were performed on individual gene datasets using Bayesian inference (see Supplementary Table 1 for details on the taxa included in the analyses). Prior to analyses, the 'best-fitting' models of nucleotide substitution were estimated based on the Bayesian information criterion (BIC) in jModelTest v. 2.1.4 [36]. BI analysis was carried out with MrBayes v. 3.2.7 [37] on the CIPRES Science Gateway v.3.3 [38] using Markov chain Monte Carlo (MCMC) searches on two simultaneous runs of four

chains for $10^{7}$ generations, sampling trees every $10^{3}$ generations. The "burn-in" determined by stationarity of InL assessed with Tracer v.1.5 [39] was set for the first 25\% of the trees sampled, and a consensus topology and nodal support estimated as posterior probability values [40] were calculated from the remaining trees. Phylogenetic trees were visualized and finalised in FigTree v. 1.4.4 [41]. The newlygenerated sequences were deposited in GenBank under accession numbers: XXXXXX-XXXXXX.

\section{Results}

Three out of the 1,745 examined $P$. cingulata were infected with avian schistosomes. The infected snails were collected at two distinct localities named Genaveh $(n=2$; prevalence $=1 \%)$ and Jask $(n=1$; prevalence $0.4 \%$ ) (see also Fig. 1 for sampling locations). Successful amplifications were achieved for $28 \mathrm{~S}$ and $\operatorname{cox} 1$ for all three isolates. The yielded sequences were $1,254-1,285 \mathrm{bp}$ (28S rDNA) and 344$730 \mathrm{bp}$ long $(\operatorname{cox} 1)$. The two isolates from Genaveh shared an identical 28S rDNA sequence with a published isolates for Ornithobilharzia canaliculata from the USA ex Larus delawarensis and $L$. occidentalis (AF167085, AY157248, KP734309), while the isolate from Jask differed by 2.3\% (29 bp) from the former ones. A BLASTn search indicated that the latter isolate belonged to the genus Austrobilharzia. The novel isolate from Iran differed by $12-19$ bp $(0.9-1.8 \%)$ from the published representatives of the 
genus. The closest relative was an otherwise unidentified isolate from the same host species, $P$. cingulata, from off Kuwait (12 bp, $0.9 \%$ genetic difference).

Cox 1 sequence divergence between our two isolates of 0 . canaliculata from Iran was 9 bp (2.6\%). In contrast to the identical $28 \mathrm{~S}$ sequences between the novel and published isolates for 0 . canaliculata, cox 1 sequences differed substantially, ranging between $27-32$ bp $(7.9-9.3 \%)$. The single isolate from Jask differed by $1.66-1.82 \%$ (49-55 bp; $16.3-18.2 \%$ ) from the novel isolates for 0 . canaliculata, and by 59 bp (20.1\%) from Austrobilharizia sp. from Kuwait. Interspecific sequence divergence within Austrobilharzia was within the range of 21-63 bp (9.7-20.1\%). However, the intergeneric divergence between the isolates for Ornithobilharzia and Austrobilharzia was somehow lower that the interspecific divergence for Austrobilharzia, i.e., 25-61 bp (7.7-18.4\%). A single cox1 isolate for Austrobilharzia variglandis ex Larus sp. from Canada was not included in the sequence comparisons as it covers a distinct region of the $\operatorname{cox} 1$ gene and did not align with the remaining published isolates.

The aligned $28 S$ dataset consisted of 76 terminals ( 2 newly-sequenced) and it was 1,370 bp long, 78 of which were excluded prior to analyses. The cox 1 dataset comprised 66 terminals and it was $1,031 \mathrm{bp}$ long. Analyses of the individual genes resulted in well-resolved trees (Fig. 2). The 28S rDNA hypothesis, presented in Fig. 2A, included representatives of all named and molecularly characterised species-level lineages except for the monotypic Jilinobilharzia as molecular data currently do not exist (the single species, J. crecci Liu \& Bai, 1976, has not been reported since its original description). Therefore, the ingroup taxa consisted of representative sequences of the families Schistosomatidae and the closely related Spirorchiidae (see Supplementary Table S1). The outgroup comprised representative of the Aporocotylidae and it was informed from previous phylogenies [42]. Our phylogenetic hypothesis recovered the spirorchiids in freshwater crocodilian and testudine hosts as the earliest diverging lineage. Spirorchiids with marine life-cycle clustered in a distinct clade basal to the Schistosomatidae. Members parasitic in marine testudines were identified as a distinct clade sister to all remaining schistosomes parasitic in birds and mammals. Schistosomes clustered into four distinct lineages: (i) an earlier diverging and strongly supported clade comprising the marine Ornithobilharzia and Austrobilharzia (ii) Macrobilharzia - a genus known from suliform birds which was resolved as a distinct lineage basal to the freshwater schistosomes, and two strongly-supported multi-taxa sister clades predominantly of (iii) mammalian and (iv) avian schistosomes. The mammalian schistosomes were further recovered as three distinct lineages: (i) Bivitelobilharzia - a genus including species parasitic in elephants and rhinoceros were recovered in a strongly-supported sub-clade sister to the main clade of mammalian schistosomes; (ii) a sub-clade of Schistosoma spp. with South East Asian distribution; and (iii) a clade comprising African representatives of Schistosoma. The North American mammalian representatives, Heterobilharzia and Schistosomatium were resolved as closer relatives to the large clade of avian schistosomes (Trichobilharzia + Marinabilharzia + Dendritobilharzia + Gigantobilharzia + Nasusbilharzia + Riverabilharzia). The remaining avian schistosomes clustered in two sister monophyletic clades with generally strong support for the major nodes. Bilharziella and Nasusbilharzia were recovered as earlier diverging to the two sister strongly-supported subclades of Gigantobilharzia + Dendritobilharzia + Marinabilharzia + Riverabilharzia, and Trichobilharzia + Allobilharzia + Anserobilharzia. 
The cox 1 tree was well-resolved and received strong support for most of the internal nodes (Fig. 2B). Taxa largely grouped in consistence with the $28 \mathrm{~S}$ solution. Ornithobilharzia and Austrobbilharzia clustered into two distinct strongly-supported sister clades. The newly-sequenced isolate from Jask clustered in a clade with $A$. variglandis and $A$. terrigalensis, however, the isolate for $O$. canaliculata clustered with otherwise unidentified isolate labelled as Austrobilharzia sp. from Kuwait indicating a possible misidentification of the latter one. This was further confirmed by the high levels of genetic divergence in comparison with the other isolates of Austrobilharzia as indicated above.

\section{Discussion}

The present study is part of an effort to document the trematode diversity in P. cingulata (Gmelin, 1791), one of the most abundant snail species along the Iranian coast $[25,26,43]$. Sequence data for two species of marine avian schistosomes, Ornithobilharzia canaliculata (Rudolphi, 1819) and a putative new species of Austrobilharzia Johnston, 1917, are represented in a phylogenetic context together with other members of the family Schistosomatidae. This is the first report and molecular evidence for Ornithobilharzia canaliculata (Rudolphi, 1819) infecting P. cingulata as an intermediate host and it is the first partial molecular elucidation of its life-cycle. Our study adds to the diversity, host associations and phylogeny of the avian schistosomes with marine-based life-cycles, a group of schistosomes with great etiological importance.

Cercariae of the marine schistosomes are recognised as important etiological agents of human dermatitis [44-46]. Despite their importance to the public health, still very little is known about their diversity and evolution [9] as a consequence of largely under surveyed marine habitats for schistosomes worldwide [4]. This is in sharp contrast with the wealth of knowledge gathered about the mammalian and avian schistosomes with freshwater-based life-cycles, and information concerning the natural history of most marine schistosomes is scarce. The slow rates in recovering marine schistosomes, low species richness recorded in snail hosts and the convoluted taxonomy of the group, including separate taxonomic treatments of the distinct life-cycle stages, reflects the scarcity of data [47]. Matching sequence data for different life-cycle stages and across distant localities has accelerated life-cycles elucidations and hostparasite associations $[4,5]$. Although, the molecular systematics has had a major impact for the recent increase in discoveries and species delimitation, it has led to a plethora of putative new species and lineages of avian schistosomes for which only molecular data for their cercarial stages exist. Most of these putative species / species level lineages are of considerable importance due to their etiological significance. Their formal descriptions await as reliably identified adult stages are needed to help infer on their respective life- cycles and host-parasite associations.

Ornithobilharizia canalicata was originally described from Sterna galericulata in Brazil [13]. Later the species was reported from a wide range of gulls and terns across the Americas, Europe, Asia and New Zealand (see Table 1 for details). Larus dominicanus Lichtenstein and L. maculipennis Lichtenstein serve as the main hosts in the southern hemisphere; Larus delawarensis Ord, and L. occidentalis Audubon have been reported as hosts in North America and a total of 22 species of gulls and terns were reported as 
hosts across Europe and the Middle East. Despite the large number of definitive hosts, thus far the species was reported only from a single mollusc species, Lampanella minima (Gmelin), in North America. However, an experimental infection linking larval and adult stages has never been conducted. An important result from our study is the molecular confirmation of the conspecificity of our isolate from $P$. cingulata with the published isolate of an adult worm from North America. Matching sequence data for isolates from different life-cycle stages collected from disparate locations and times, provides unambiguous link between adult and larval stages from natural infections and accelerates species circumscription. The intercontinental distribution and the rather narrowly defined clade of gulls is instructive for studies on the transmission of avian zoonoses and the epidemiology of human cercarial dermatitis. The trans-continental distribution of Ornithobilharzia across the America, Europe and Asia is an explicit example that species dispersal is determined by the most vagile, bird host, involved in the trematode life-cycle. It is widely accepted that the distribution of the definitive host governs the larval trematode recruitment in the snail (first) intermediate host ([48] and references therein). Resolving the relative roles of both host ecology and phylogeny in respect to the parasite transmission dynamics over evolutionary times would require further concerted efforts. Phylogenetic studies based on denser and wide taxon sampling including diverse intermediate and definitive hosts is crucial for building up an improved framework and better interpretation of the schistosome biology [3]. Further, good documentation and re-evaluation of the morphological charters of the respective larval stages is urgently needed. 
Table 1

Records of Ornithobilharzia spp. and Austrobilharzia spp.

\begin{tabular}{|c|c|c|c|}
\hline Species & Host & Locality & Reference \\
\hline \multirow[t]{17}{*}{$\begin{array}{l}\text { Austrobilharzia } \\
\text { terrigalensis Johnston, } \\
1917\end{array}$} & $\begin{array}{l}\text { Batillaria australis (Quoy } \\
\text { \& Gaimard) }\end{array}$ & $\begin{array}{l}\text { Australia: Iron } \\
\text { Cove, Sedney } \\
\text { Harbour }\end{array}$ & Lockyer et al. (2003) [1] \\
\hline & $\begin{array}{l}\text { Batillaria australis (Quoy } \\
\text { \& Gaimard) }\end{array}$ & Australia & Walker (1979) [2] \\
\hline & $\begin{array}{l}\text { Batillaria australis (Quoy } \\
\text { \& Gaimard) }\end{array}$ & $\begin{array}{l}\text { Australia: Swan } \\
\text { Estuary }\end{array}$ & Appleton (1983b) [3] \\
\hline & $\begin{array}{l}\text { Batillaria australis (Quoy } \\
\text { \& Gaimard) }\end{array}$ & $\begin{array}{l}\text { Australia: Swan } \\
\text { Estuary }\end{array}$ & Appleton (1983a) [4] \\
\hline & $\begin{array}{l}\text { Batillaria australis (Quoy } \\
\text { \& Gaimard) }\end{array}$ & Australia & $\begin{array}{l}\text { Johnston (1917) [5] sensu } \\
\text { Farley (1971) [6] }\end{array}$ \\
\hline & $\begin{array}{l}\text { Batillaria australis (Quoy } \\
\& \text { Gaimard) }\end{array}$ & Australia & Appleton (1984) [7] \\
\hline & $\begin{array}{l}\text { Batillaria australis (Quoy } \\
\text { \& Gaimard) }\end{array}$ & $\begin{array}{l}\text { Australia: } \\
\text { Narrabeen } \\
\text { Lagoon }\end{array}$ & Bearup (1956) [8] \\
\hline & $\begin{array}{l}\text { Cerithideopsis } \\
\text { scalariformis (Say) }\end{array}$ & North America & Holliman (1961)[9] \\
\hline & $\begin{array}{l}\text { Cerithideopsis } \\
\text { scalariformis (Say) }\end{array}$ & North America & $\begin{array}{l}\text { Short and Holliman } \\
\text { (1961) [10] }\end{array}$ \\
\hline & Ilyanassa obsoleta (Say) & USA & $\begin{array}{l}\text { Miller \& Northup (1926) } \\
\text { [11] sensu Farely (1971) } \\
\text { [6] }\end{array}$ \\
\hline & Ilyanassa obsoleta (Say) & USA & $\begin{array}{l}\text { Camishion et al. (1981) } \\
\text { [12] }\end{array}$ \\
\hline & Ilyanassa obsoleta (Say) & $\begin{array}{l}\text { USA: New } \\
\text { Jersey }\end{array}$ & $\begin{array}{l}\text { Zibulewsky et al. (1982) } \\
\text { [13] }\end{array}$ \\
\hline & Ilyanassa obsoleta (Say) & $\begin{array}{l}\text { USA: Atlantic } \\
\text { coast }\end{array}$ & Bacha et al. (1982) [14] \\
\hline & Ilyanassa obsoleta (Say) & $\begin{array}{l}\text { USA: Atlantic } \\
\text { coast }\end{array}$ & Wood \& Bacha (1983) [15] \\
\hline & Ilyanassa obsoleta (Say) & $\begin{array}{l}\text { USA: North } \\
\text { Carolina }\end{array}$ & Sindermann (1956) [16] \\
\hline & Ilyanassa obsoleta (Say) & USA: California & $\begin{array}{l}\text { Grodhaus \& Keh (1958) } \\
\text { [17] }\end{array}$ \\
\hline & $\begin{array}{l}\text { Littorina pintado (W. } \\
\text { Wood) }\end{array}$ & US: Hawaii & George et al. (1954) [18] \\
\hline
\end{tabular}




\begin{tabular}{|c|c|c|c|}
\hline Species & Host & Locality & Reference \\
\hline & $\begin{array}{l}\text { Littorina pintado (W. } \\
\text { Wood) }\end{array}$ & Hawaii & $\begin{array}{l}\text { Chu \& Cutress (1954) [19] } \\
\text { sensu Farely (1971) [6] }\end{array}$ \\
\hline & Planaxis sulcatus (Born) & $\begin{array}{l}\text { Australia: GBR, } \\
\text { Heron Island }\end{array}$ & Rohde (1977) [20] \\
\hline & Planaxis sulcatus (Born) & Australia & Rohde (1977) [20] \\
\hline & Anous minutus (L.) & $\begin{array}{l}\text { Australia: GBR, } \\
\text { Heron Island }\end{array}$ & Rohde (1977) [20] \\
\hline & Arenaria interpres (L.) & Hawaii & $\begin{array}{l}\text { Chu \& Cutress (1954) [19] } \\
\text { sensu Farely (1971) [6] }\end{array}$ \\
\hline & Arenaria interpres (L.) & US: Hawaii & George et al. (1954) [18] \\
\hline & Aythya affinis (Eyton) & $\begin{array}{l}\text { USA: } \\
\text { Massatchusetts }\end{array}$ & $\begin{array}{l}\text { Price (1929) [21] sensu } \\
\text { Farely (1971) [6] }\end{array}$ \\
\hline & $\begin{array}{l}\text { Aythya valisineria } \\
\text { (Wilson) }\end{array}$ & Canada & $\begin{array}{l}\text { McLeod (1940) [22] sensu } \\
\text { Farley (1971) [6] }\end{array}$ \\
\hline & $\begin{array}{l}\text { Larus californicus } \\
\text { Lawrence }\end{array}$ & USA: Wyoming & Keppner (1973) [23] \\
\hline & $\begin{array}{l}\text { Larus novaehollandiae } \\
\text { Stephens }\end{array}$ & Australia & $\begin{array}{l}\text { Johnston }(1917)[24] \\
\text { sensu Farley }(1971)[6]\end{array}$ \\
\hline & $\begin{array}{l}\text { Larus novaehollandiae } \\
\text { Stephens }\end{array}$ & $\begin{array}{l}\text { Australia: Swan } \\
\text { Estuary }\end{array}$ & Appleton (1983) [25] \\
\hline & $\begin{array}{l}\text { Larus novaehollandiae } \\
\text { Stephens }\end{array}$ & $\begin{array}{l}\text { Australia: Swan } \\
\text { Estuary }\end{array}$ & Appleton (1984) [7] \\
\hline & Mergus serrator $\mathrm{L}$. & USA & $\begin{array}{l}\text { Penner (1953) [26] sensu } \\
\text { Farley (1971) [6] }\end{array}$ \\
\hline & Egretta sacra (Gmelin) & Australia & Rohde (1977) [20] \\
\hline & Egretta sacra (Gmelin) & $\begin{array}{l}\text { Australia: GBR, } \\
\text { Heron Island }\end{array}$ & Rohde (1977) [20] \\
\hline & $\begin{array}{l}\text { Larus novaehollandiae } \\
\text { Stephens }\end{array}$ & Australia & $\begin{array}{l}\text { Johnston }(1917,1941) \\
\text { [24] [27], Appleton (1984) } \\
\text { [7] }\end{array}$ \\
\hline & $\begin{array}{l}\text { Larus novaehollandiae } \\
\text { Stephens }\end{array}$ & $\begin{array}{l}\text { Australia: } \\
\text { Terrigal, near } \\
\text { Sydney }\end{array}$ & Johnston (1917) [24] \\
\hline & $\begin{array}{l}\text { Larus novaehollandiae } \\
\text { Stephens }\end{array}$ & $\begin{array}{l}\text { Australia: GBR, } \\
\text { Heron Island }\end{array}$ & Rohde (1977) [20] \\
\hline & $\begin{array}{l}\text { Larus novaehollandiae } \\
\text { Stephens }\end{array}$ & Australia & Rohde (1977) [20] \\
\hline
\end{tabular}




\begin{tabular}{|c|c|c|c|}
\hline \multirow[t]{3}{*}{ Species } & Host & Locality & Reference \\
\hline & Larus hemprichii Bruch & Red Sea & $\begin{array}{l}\text { Witenberg and Lengy } \\
\text { (1967) [28] }\end{array}$ \\
\hline & “Canary”(exp.) & USA: California & $\begin{array}{l}\text { Grodhaus \& Keh (1958) } \\
\text { [17] }\end{array}$ \\
\hline \multirow{15}{*}{$\begin{array}{l}\text { Austrobilhariza } \\
\text { variglandis (Miller \& } \\
\text { Northup, 1926) }\end{array}$} & Ilyanassa obsoleta (Say) & $\begin{array}{l}\text { USA: Delaware } \\
\text { estuaries }\end{array}$ & Curtis (1997) [29] \\
\hline & Ilyanassa obsoleta (Say) & $\begin{array}{l}\text { USA: Delaware } \\
\text { estuaries }\end{array}$ & $\begin{array}{l}\text { Curtis \& Tanner (1999) } \\
\text { [30] }\end{array}$ \\
\hline & Ilyanassa obsoleta (Say) & $\begin{array}{l}\text { USA: Mumford } \\
\text { Cove, } \\
\text { Connecticut }\end{array}$ & Barber \& Caira (1995) [31] \\
\hline & Ilyanassa obsoleta (Say) & North America & $\begin{array}{l}\text { Grodhaus and Keh (1958) } \\
\text { [17], Curtis (1997) [29], } \\
\text { Leighton et al. (2004) [32] }\end{array}$ \\
\hline & Ilyanassa obsoleta (Say) & $\begin{array}{l}\text { USA: Little Egg } \\
\text { Inlet, New } \\
\text { Jersey }\end{array}$ & Ferris \& Bacha (1986) [33] \\
\hline & $\begin{array}{l}\text { Littorina pintado (W. } \\
\text { Wood) }\end{array}$ & USA: Hawaii & Chu \& Cutress (1954) [19] \\
\hline & $\begin{array}{l}\text { Anous stolidus pileatus } \\
\text { (Scopoli) }\end{array}$ & USA: Hawaii & Chu \& Cutress (1954) [19] \\
\hline & Arenaria interpres (L.) & USA: Hawaii & Chu \& Cutress (1954) [19] \\
\hline & $\begin{array}{l}\text { Aythya affinis (Eyton, } \\
\text { 1838) }\end{array}$ & $\begin{array}{l}\text { USA: Eastern } \\
\text { part }\end{array}$ & Price (1929) [21] \\
\hline & Branta canadensis (L.) & $\begin{array}{l}\text { USA: Mumford } \\
\text { Cove, } \\
\text { Connecticut }\end{array}$ & Barber \& Caira (1995) [31] \\
\hline & $\begin{array}{l}\text { Larus argentatus } \\
\text { Pontoppidan }\end{array}$ & $\begin{array}{l}\text { USA: Mumford } \\
\text { Cove, } \\
\text { Connecticut }\end{array}$ & Barber \& Caira (1995) [31] \\
\hline & $\begin{array}{l}\text { Larus argentatus } \\
\text { Pontoppidan (exp.) }\end{array}$ & USA & $\begin{array}{l}\text { Stunkard \& Hinchliffe } \\
(1951,1952)[31,32]\end{array}$ \\
\hline & Larus delawarensis Ord & $\begin{array}{l}\text { USA: Mumford } \\
\text { Cove, } \\
\text { Connecticut }\end{array}$ & Barber \& Caira (1995) [31] \\
\hline & Larus delawarensis Ord & USA: Delaware & Lockyer et al. (2003) [1] \\
\hline & Larus marinus $\mathrm{L}$. & $\begin{array}{l}\text { USA: Mumford } \\
\text { Cove, } \\
\text { Connecticut }\end{array}$ & Barber \& Caira (1995) [31] \\
\hline
\end{tabular}




\begin{tabular}{|c|c|c|c|}
\hline Species & Host & Locality & Reference \\
\hline & Larus marinus $\mathrm{L}$. & North America & $\begin{array}{l}\text { Keppner (1973) [23], } \\
\text { Barber and Caira (1995) } \\
\text { [31] }\end{array}$ \\
\hline & $\begin{array}{l}\text { Larus novaehollandiae } \\
\text { Stephens }\end{array}$ & $\begin{array}{l}\text { Australa: Heron } \\
\text { Island }\end{array}$ & Rohde (1977) [20] \\
\hline & Mergus serrator L. & USA & Penner (1953) [26] \\
\hline & Mergus serrator L. & $\begin{array}{l}\text { North America: } \\
\text { Hawaii }\end{array}$ & Penner (1953b) [36] \\
\hline & $\begin{array}{l}\text { Phalacrocorax auritus } \\
\text { (Lesson) }\end{array}$ & $\begin{array}{l}\text { USA: Mumford } \\
\text { Cove, } \\
\text { Connecticut }\end{array}$ & Barber \& Caira (1995) [31] \\
\hline & $\begin{array}{l}\text { Phalacrocorax auritus } \\
\text { (Lesson) }\end{array}$ & North America & $\begin{array}{l}\text { Barber and Caira (1995) } \\
\text { [31] }\end{array}$ \\
\hline & $\begin{array}{l}\text { Sterna fusccata } \\
\text { oahuensis (L.) }\end{array}$ & USA: Hawaii & Chu \& Cutress (1954) [19] \\
\hline $\begin{array}{l}\text { Austrobilharzia odhneri } \\
\text { (Faust, 1924) Farley, } \\
1971\end{array}$ & Numenius arquata (L.) & China & Faust (1924) [37] \\
\hline \multirow[t]{3}{*}{$\begin{array}{l}\text { Austrobilharzia penneri } \\
\text { Short \& Holliman, } 1961\end{array}$} & $\begin{array}{l}\text { Cerithideopsis } \\
\text { scalariformis (Say) }\end{array}$ & North America & Holliman (1961) [9] \\
\hline & $\begin{array}{l}\text { Cerithideopsis } \\
\text { scalariformis (Say) }\end{array}$ & North America & $\begin{array}{l}\text { Short and Holliman } \\
\text { (1961) [10] }\end{array}$ \\
\hline & $\begin{array}{l}\text { Cerithidea scalariformis } \\
\text { and "parakeets, chickens } \\
\text { and pigeons (exp.)" }\end{array}$ & $\begin{array}{l}\text { USA: Florida, } \\
\text { Northern Gulf } \\
\text { coast }\end{array}$ & $\begin{array}{l}\text { Short \& Holliman (1961) } \\
\text { [10] }\end{array}$ \\
\hline \multirow[t]{6}{*}{ Austrobilhariza sp. } & $\begin{array}{l}\text { Cerithideopsis } \\
\text { californica (Haldeman) }\end{array}$ & $\begin{array}{l}\text { USA: Bolinas } \\
\text { Lagoon, in } \\
\text { central } \\
\text { California }\end{array}$ & Sousa (1993) [38] \\
\hline & Cerithidia sp. & North America & Martin (1972) [39] \\
\hline & Littorina pintado Wood & $\begin{array}{l}\text { North America: } \\
\text { Hawaii }\end{array}$ & Chu (1952) [40] \\
\hline & $\begin{array}{l}\text { Pirenella cingulata } \\
\text { (Gmelin) }\end{array}$ & $\begin{array}{l}\text { Kuwait: Kuwait } \\
\text { Bay }\end{array}$ & $\begin{array}{l}\text { Al-Kandari et al. (2012) } \\
\text { [41] }\end{array}$ \\
\hline & $\begin{array}{l}\text { Pirenella cingulata } \\
\text { (Gmelin) }\end{array}$ & Kuwait Bay & $\begin{array}{l}\text { Al-Kandari et al. (2012) } \\
\text { [41] }\end{array}$ \\
\hline & $\begin{array}{l}\text { Nassarius (Hinia) } \\
\text { reticulatus (L.) }\end{array}$ & Italy & $\begin{array}{l}\text { Canestri-Trotti et al. } \\
(2001) \text { [42] }\end{array}$ \\
\hline
\end{tabular}




\begin{tabular}{|c|c|c|c|}
\hline Species & Host & Locality & Reference \\
\hline & $\begin{array}{l}\text { Littorina keenae } \\
\text { Rosewater }\end{array}$ & North America & Penner (1950) [43] \\
\hline & Planaxis sulcatus (Born) & $\begin{array}{l}\text { Kuwait: Kuwait } \\
\text { Bay }\end{array}$ & $\begin{array}{l}\text { Abdul-Salam \& Sreelatha } \\
\text { (2004) [44] }\end{array}$ \\
\hline & Anous minutus Boie & $\begin{array}{l}\text { North America: } \\
\text { Hawaii }\end{array}$ & Chu (1954) [19] \\
\hline & Gavia immer(Brünnich) & North America & $\begin{array}{l}\text { Kinsella and Forrester } \\
\text { (1999) [45] }\end{array}$ \\
\hline & $\begin{array}{l}\text { Larus dominicanus } \\
\text { Lichtenstein }\end{array}$ & South Africa & $\begin{array}{l}\text { Appleton }(1982,1986) \\
\text { [46] [47], }\end{array}$ \\
\hline & $\begin{array}{l}\text { Larus dominicanus } \\
\text { Lichtenstein }\end{array}$ & $\begin{array}{l}\text { South Africa: } \\
\text { Umgeni Estuary }\end{array}$ & Appleton (1982) [46] \\
\hline & Onychoprion fuscatus $\mathrm{L}$. & $\begin{array}{l}\text { North America: } \\
\text { Hawaii }\end{array}$ & Chu (1954) [19] \\
\hline & $\begin{array}{l}\text { Pelecanus occidentalis } \\
\text { L. }\end{array}$ & North America & $\begin{array}{l}\text { Courtney and Forrester } \\
\text { (1973) [48] }\end{array}$ \\
\hline \multirow{10}{*}{$\begin{array}{l}\text { Ornithobilharzia } \\
\text { canaliculata (Rudolphi, } \\
\text { 1819) }\end{array}$} & $\begin{array}{l}\text { Lampanella minima } \\
\text { (Gmelin) }\end{array}$ & North America & $\begin{array}{l}\text { Penner (1953) [49], } \\
\text { Morales et al. (1971) [50] }\end{array}$ \\
\hline & $\begin{array}{l}\text { Lampanella minima } \\
\text { (Gmelin) }\end{array}$ & USA: Florida & Morales et al. (1971) [50] \\
\hline & $\begin{array}{l}\text { Lampanella minima } \\
\text { (Gmelin) }\end{array}$ & Brazil & $\begin{array}{l}\text { Travassos et al. (1969) } \\
\text { [51] }\end{array}$ \\
\hline & $\begin{array}{l}\text { Chlidonias hybrida } \\
\text { (Pallas) }\end{array}$ & Caspian Sea & $\begin{array}{l}\text { Saidov (1953) [52], } \\
\text { Bykhovskaya (1962) [53] }\end{array}$ \\
\hline & $\begin{array}{l}\text { Hydroprogne caspia } \\
\text { (Pallas) }\end{array}$ & $\begin{array}{l}\text { Black Sea, } \\
\text { Central Europe }\end{array}$ & $\begin{array}{l}\text { Leonov (1957) [54], } \\
\text { Macko (1963) [55] }\end{array}$ \\
\hline & $\begin{array}{l}\text { Hydroprogne caspia } \\
\text { (Pallas) }\end{array}$ & West Siberia & Bykhovskaya (1953) [56] \\
\hline & $\begin{array}{l}\text { Ichthyaetus } \\
\text { melanocephalus } \\
\text { Temminck }\end{array}$ & $\begin{array}{l}\text { Calabria, } \\
\text { Southern Italy }\end{array}$ & Santoro et al. (2011) [57] \\
\hline & Larus fuscus L. & Red Sea & $\begin{array}{l}\text { Witenberg and Lengy } \\
\text { (1967) [28] }\end{array}$ \\
\hline & $\begin{array}{l}\text { Larus argentatus } \\
\text { Pontoppidan }\end{array}$ & West Siberia & Bykhovskaya (1953) [56] \\
\hline & Larus cachinnans Pallas & Spain, Galicia & $\begin{array}{l}\text { Sanmartín et al. (2005) } \\
\text { [58] }\end{array}$ \\
\hline
\end{tabular}




\section{Host}

Larus canus L.

Larus delawarensis Ord

Larus delawarensis Ord

Larus delawarensis Ord

Larus dominicanus

Lichtenstein

Larus dominicanus

Lichtenstein

Larus dominicanus

Lichtenstein

Larus maculipennis

Lichtenstein

Larus fuscus $\mathrm{L}$.

Larus fuscus $\mathrm{L}$.

Larus hemprichii Bruch

Larus ichthyaetus Pallas

Hydrocoloeus

melanocephalus

(Temminck

Hydrocoloeus minutus

(Pallas)

Larus occidentalis

Audubon

Larus ridibundus $\mathrm{L}$.

Puffinus kuhli (Boie)

Sterna galericulata

Sterna hirundo L.
Locality

Black Sea

Canada

USA: Donley

USA: Texas

Brazil

New Zealand

Argentina

Argentina

North Russia,

Red Sea County, Texas

\section{Reference}

Popova (1927) [59],

Bykhovskaya (1962) [53]

McLeod (1940) [22]

Lockyer et al. (2003) [1]

Snyder \& Locker (2000)

[60]

Travassos (1942) [61]

Rind (1984) [62]

Szidat (1964) [63]

Szidat (1964) [63]

Shygin (1954) [63];

Bykhovskaya (1962) [53];

Witenberg \& Lengy (1967) [28]

Sweden

Odhner (1912) [64]

Red Sea

Witenberg \& Lengy (1967) [28]

Black Sea

Leonov (1957) [54]

Italy

Parona \& Ariola (1896)

[65]

Caspian Sea

Saidov (1953) [52],

Bykhovskaya (1962) [53]

USA

Jothikumar et al. (2015) [66]

North Russia,

Caspian Sea

Shigin (1954) [67], Saidov

(1953) [52], Bykhovskaya (1962) [53]

West Siberia

Bykhovskaya (1953) [56]

Red Sea

Witennberg (1929) [68]

Brazil

Rudolphi (1819) [69]

Czech Republic Kolářová et al. (2013) [70] 


\begin{tabular}{|llll|}
\hline Species & Host & Locality & Reference \\
\hline & $\begin{array}{l}\text { Sterna sandwichensis } \\
\text { Latham }\end{array}$ & Black Sea & Leonov (1957) [54] \\
\hline $\begin{array}{l}\text { Ornithobilharzia sp. (? } \\
\text { canaliculata) }\end{array}$ & Eudocimus albus (L.) & North America & $\begin{array}{l}\text { Bush and Forrester (1976) } \\
\text { [71] }\end{array}$ \\
\hline $\begin{array}{l}\text { Ornithobilharzia lari } \\
\text { McLeod, 1937 }\end{array}$ & $\begin{array}{l}\text { Larus argentatus } \\
\text { Pontoppidan }\end{array}$ & $\begin{array}{l}\text { Canada. Nova } \\
\text { Scotia }\end{array}$ & McLeod (1937) [22] \\
\hline & Larus delawarensis Ord & $\begin{array}{l}\text { Canada. Nova } \\
\text { Scotia }\end{array}$ & McLeod (1940) [22] \\
\hline $\begin{array}{l}\text { Ornithobilharzia } \\
\text { amplitesta Gubanov \& } \\
\text { Mamaev in Mamaev, } \\
1959\end{array}$ & Tringa glareola L. & Russia & McLeod (1940) [22] \\
\hline
\end{tabular}

Successful transmission of parasites with complex life-cycles requires an overlap of all hosts involved. The invertebrate first intermediate host has been recognised as one of the keys to the evolutionary expansions of the digenean trematodes. All schistosomes (marine and freshwater) are known to develop in gastropods. The basal position of the marine schistosomes (Austrobilharzia and Ornithobilharzia) has been considered as an indication for a successful ancestral marine-transmitted bird parasite transmission in colonising both freshwater snails and mammals [42] The schistosomes emerging from marine heterobranch snails (Haminea and Siphonaria) and also recorded in penguins are a well-known example of secondary colonisation of marine habitats by the schistosomes [7, 8, 47]. Considering the snail intermediate hosts, in at least two instances, even congeneric schistosomes depend on markedly divergent gastropod lineages, i.e., pulmonates versus opisthobranchs or caenogastropods, indicative for an extensive host switching within the molluscan hosts [49] and references therein).

Avian schistosomes are known to have colonized a wide range of snail hosts with representatives from 15 snail families: (i) caenogastropods from both marine (Potamididae, Batilariidae, Nassariidae, and Littorinidae; $[16,17,50-52]$ and freshwater environments (Thiaridae, Ampullariidae, Hydrobiidae, and Semisulcospiridae [50, 53, 54-56]; (ii) heterobranchs from marine (Haminoeidae; [10, 11], and freshwater (Valvatidae; [57]; and (iii) pulmonates from marine (Siphonariidae; [12]) and freshwater (Physidae, Lymnnaeidae, Planorbidae, and Chilinidae; $[1,3,50,58,59]$. Reports of avian schistosomes from distantly related snail intermediate hosts are not rare and invoke questions on the proper identification of the respective parasites. Dendritobilharzia pulverulenta [60] Skrjabin, 1924 has been reported from two distinct planorbid snails Gyraulus Charpentier, 1837 and Anisus vortex (L.) [61]. Gyraulus has been reported as a natural host of the species in North America and New Zealand, while Anisus and Planorbis planorbis (L.) have been reported as hosts in Europe. Trichobilharzia jequitibaensis Leite, Costa, \& Costa, 1978 is known to infect both lymnaeid and physid snails [62]. Austrobilharzia terrigalensis has been considered to utilise distinct snail hosts across its distributional range in Australia (Batillaria australis 
(Quoy \& Gaimard)), North America (Cerithideopsis scalariformis (Say), and Ilyanassa obsoleta (Say) and the Pacific (Littorina pintado (W. Wood)). Intercontinental and trans-hemispheric distribution has been recently reported for Trichobilharzia querquedule [63] [64], however the species is known as a parasite specific to Physa spp. as an intermediate host.

In respect to their definitive hosts, predominant part of the schistosomes is known as parasitises in birds. Currently a total of 13 genera are known as parasites in birds: Austrobilharzia Johnston, 1917, Allobilharzia (1 species), Anserobilharzia (1 species), Bilharziella (1 species), Dendritobilharzia (2 species) Gigantobilharzia (c.14 species), Jilinobilharzia (1 species), Macrobilharzia Travassos, 1922 (2 species), Ornithobilharzia Odhner, 1912; Nasusbulharzia Flores, [65] (1 species), Marinabilharzia (1 species), Riverabilharzia (1 species) [5] and Trihobilharzia (c.35 species). Among them, species of Trichobilharzia have been subject of the most intensive research due to their recognition as leading aetiological agents of human cercarial dermatitis ([66] and references therein). The genus represents the most specious among the bird schistosomes with about 35 species or species level lineages. However, about $65 \%$ of the remaining avian schistosomes, yet remain largely unstudied with fragmentary data on their diversity, biology and ecology. This is especially true in respect to the marine schistosomes for which life-cycle information lags behind their freshwater relatives. Despite the great efforts made so far in building up a comprehensive framework for the study of schistosome diversity, still considerable data are needed for assessing their true diversity due to the difficulty of directly relating larval and adult stages. Consistent efforts towards the use of integrative approach including collecting novel data from diverse host species and combining them thorough morphological examination, traditional systematics, classical taxonomy and phylogenetics have been proven as most valuable practice providing important information to the better understanding of the biodiversity and evolutionary relationships of the group [2-4].

\section{Conclusion}

Our study strongly suggests that the biodiversity of the marine schistosomes is underestimated. The extensive discovery-based studies about schistosome diversity during the last two decades has revealed an immense diversity of avian schistosomes. However, unravelling their true diversity across hosts and geographic areas have been hindered by the difficulties of matching distinct life-cycle stages. There is still a need for more records of identifiable adult and larval schistosomes. Our study is a crucial step towards better understanding of important properties of marine schistosome biology and ecology, their patterns of diversification and distribution.

\section{Declarations}

\section{Supplementary information}

Additional file 1: Table S1. Summary data for $\operatorname{cox} 1$ and $28 \mathrm{~S}$ sequences retrieved from GenBank.

\section{Acknowledgements}


We are indebted to professor Martin Wahl, GEOMAR Helmholtz Centre for Ocean Research, Kiel, for his generous support during the study. We sincerely thank Mr. Amir Reza Heidari Motahar for the immense help during the field work in Iran. We gratefully acknowledge the help provided by Mrs. Mehregan Heidari and all members of the Parasitology group at Hormozgan University in Iran for the support with logistics. MK benefited from "Studienstiftung des deutschen Volkes" PhD fellowship and research grant by benthic ecology group of GEOMAR.

\section{Authors' contributions}

MK and SG: conceived the study, obtained samples, carried out the sequencing, performed analyses prepared the first draft of the manuscript. MK, DT, JS, SG discussed the results and helped draft the manuscript. All authors read and approved the final manuscript.

\section{Availability of data and material}

All data are available in the main manuscript or additional supporting files.

\section{Competing interests}

The authors declare that they have no competing interests.

\section{References}

1. Brant, S. V; Loker, E.S. Molecular systematics of the avian schistosome genus Trichobilharzia (Trematoda: Schistosomatidae) in North America. J. Parasitol. 2009, 95, 941-963.

2. Horák, P.; Mikeš, L.; Lichtenbergová, L.; Skála, V.; Soldánová, M.; Brant, S.V. Avian schistosomes and outbreaks of cercarial dermatitis. Clin. Microbiol. Rev. 2015, 28, 165-190.

3. Brant, S. V.; Morgan, J.A.T.; Mkoji, G.M.; Snyder, S.D.; Rajapakse, R.P.V.J.; Loker, E.S. AN APPROACH TO REVEALING BLOOD FLUKE LIFE CYCLES, TAXONOMY, AND DIVERSITY: PROVISION OF KEY REFERENCE DATA INCLUDING DNA SEQUENCE FROM SINGLE LIFE CYCLE STAGES. J. Parasitol. 2006, 92, 77-88, doi:10.1645/GE-3515.1.

4. Brant, S. V; Loker, E.S. Discovery-based studies of schistosome diversity stimulate new hypotheses about parasite biology. Trends Parasitol. 2013, 29, 449-459.

5. Lorenti, E.; Brant, S. V; Gilardoni, C.; Diaz, J.I.; Cremonte, F. Two new genera and species of avian schistosomes from Argentina with proposed recommendations and discussion of the polyphyletic genus Gigantobilharzia (Trematoda, Schistosomatidae). Parasitology 2022, 1-59.

6. Khalil, L.F. Family Schistosomatidae Stiles \& Hassall, 1898. Keys to Trematoda 2002, 1, 419-432.

7. Aldhoun, J.A.; Horne, E.C. Schistosomes in South African penguins. Parasitol. Res. 2015, 114, 237246.

8. Vanstreels, R.E.T.; Gardiner, C.H.; Yabsley, M.J.; Swanepoel, L.; Kolesnikovas, C.K.M.; Silva-Filho, R.P.; Ewbank, A.C.; Catão-Dias, J.L. Schistosomes and microfilarial parasites in Magellanic penguins. J. 
Parasitol. 2018, 104, 322-328.

9. Snyder, S.D.; Loker, E.S. Evolutionary relationships among the Schistosomatidae (Platyhelminthes: Digenea) and an Asian origin for Schistosoma. J. Parasitol. 2000, 86, 283-288.

10. Brant, S. V; Cohen, A.N.; James, D.; Hui, L.; Hom, A.; Loker, E.S. Cercarial dermatitis transmitted by exotic marine snail. Emerg. Infect. Dis. 2010, 16, 1357.

11. Leigh, W.H. The morphology of Gigantobilharzia huttoni (Leigh, 1953) an avian schistosome with marine dermatitis-producing larvae. J. Parasitol. 1955, 41, 262-269.

12. Ewers, W.H. A new intermediate host of schistosome trematodes from New South Wales. Nature 1961, 190, 283-284.

13. Rudolphi, K.A. Entozoorum synopsis cui accedunt mantissa duplex et indices locupletissimi ; Sumtibus A. Rücker,: Berolini :, 1819;

14. Odhner, T. Zum natürlichen System der digenen Trematoden.V. Zool. Anz. 1912, 41, 54-71.

15. Farley, J. A review of the family Schistosomatidae: excluding the genus Schistosoma from mammals. J. Helminthol. 1971, 45, 289-320.

16. Penner, L.R. The biology of a marine dermatitis-producing schistosome cercaria from Batillaria minima (Gmelin). J. Parasitol. 1953, 39.

17. Al-Kandari, W.Y.; Al-Bustan, S.A.; Isaac, A.M.; George, B.A.; Chandy, B.S. Molecular identification of Austrobilharzia species parasitizing Cerithidea cingulata (Gastropoda: Potamididae) from Kuwait Bay. J. Helminthol. 2012, 86, 470.

18. Martin, W.E. An annotated key to the cercariae that develop in the snail Cerithidea californica. Bull South Calif Acad Sci 1972, 71, 39-43.

19. Holliman, R.B. Larval trematodes from the Apalachee Bay area, Florida, with a checklist of known marine cercariae arranged in a key to their superfamilies. Tulane Stud. Zool. 1961, 9, 1-74.

20. Short, R.B.; Holliman, R.B. Austrobilharzia penneri, a new schistosome from marine snails. J. Parasitol. 1961, 47, 447-450.

21. Lindberg, W.F.P.D.R. Phylogeny and Evolution of the Mollusca; Univ of California Press, 2008; ISBN 0520250923.

22. Chong-ti, T. Philophthalmid larval trematodes from Hong Kong and the coast of south China. In Proceedings of the The marine flora and fauna of Hong Kong and Southern China II: proceedings of the second International Marine Biological Workshop Hong Kong, 2-24 April 1986; Hong Kong University Press, 1990; Vol. 1, p. 213.

23. Taraschewski, H. Investigations on the prevalence of Heterophyes species in twelve populations of the first intermediate host in Egypt and Sudan. J. Trop. Med. Hyg. 1985, 88, 265-271.

24. Reid, D.G.; Ozawa, T. The genus Pirenella Gray, 1847 (= Cerithideopsilla Thiele, 1929)(Gastropoda: Potamididae) in the Indo-West Pacific region and Mediterranean Sea. Zootaxa 2016, 4076, 1-91.

25. Vahidi, F.; Fatemi, S.M.R.; Danehkar, A.; Mashinchian, A.; Nadushan, R.M. Benthic macrofaunal dispersion within different mangrove habitats in Hara Biosphere Reserve, Persian Gulf. Int. J. 
Environ. Sci. Technol. 2020, 17, 1295-1306.

26. Nazeer, Z.; Khan, S.A.; Manikandan, K.; Manokaran, S.; Hsu, H.H.; Joydas, T.; Lyla, P.S. Macrofaunal assemblage in the intertidal area of Saudi Arabian Gulf Coast. Reg. Stud. Mar. Sci. 2021, 47, 101954.

27. Tkach, V.; Grabda-Kazubska, B.; Pawlowski, J.; Swiderski, Z. Molecular and morphological evidence for close phylogenetic affinities of the genera Macrodera, Leptophallus, Metaleptophallus and Paralepoderma [Digenea, Plagiorchiata]. Acta Parasitol. 1999, 44.

28. Tkach, V. V; Littlewood, D.T.J.; Olson, P.D.; Kinsella, J.M.; Swiderski, Z. Molecular phylogenetic analysis of the Microphalloidea Ward, 1901 (Trematoda: Digenea). Syst. Parasitol. 2003, 56, 1-15.

29. Littlewood, D.T.J.; Curini-Galletti, M.; Herniou, E.A. The interrelationships of Proseriata (Platyhelminthes: Seriata) tested with molecules and morphology. Mol. Phylogenet. Evol. 2000, 16, 449-466.

30. Olson, P.D.; Cribb, T.H.; Tkach, V. V; Bray, R.A.; Littlewood, D.T.J. Phylogeny and classification of the Digenea (Platyhelminthes: Trematoda). Int. J. Parasitol. 2003, 33, 733-755.

31. Bowles, J.; McManus, D.P. Rapid discrimination of Echinococcus species and strains using a polymerase chain reaction-based RFLP method. Mol. Biochem. Parasitol. 1993, 57, 231-239.

32. Miura, O.; Kuris, A.M.; Torchin, M.E.; Hechinger, R.F.; Dunham, E.J.; Chiba, S. Molecular-genetic analyses reveal cryptic species of trematodes in the intertidal gastropod, Batillaria cumingi (Crosse )*. 2005, 35, 793-801.

33. Kuraku, S.; Zmasek, C.M.; Nishimura, O.; Katoh, K. aLeaves facilitates on-demand exploration of metazoan gene family trees on MAFFT sequence alignment server with enhanced interactivity. Nucleic Acids Res. 2013, 41, W22-W28.

34. Katoh, K.; Rozewicki, J.; Yamada, K.D. MAFFT online service: multiple sequence alignment, interactive sequence choice and visualization. Brief. Bioinform. 2019, 20,1160-1166.

35. Telford, M.J.; Herniou, E.A.; Russell, R.B.; Littlewood, D.T.J. Changes in mitochondrial genetic codes as phylogenetic characters: two examples from the flatworms. Proc. Natl. Acad. Sci. 2000, 97, 11359-11364.

36. Darriba, D.; Taboada, G.L.; Doallo, R.; Posada, D. jModelTest 2: more models, new heuristics and parallel computing. Nat. Methods 2012, 9, 772.

37. Ronquist, F.; Teslenko, M.; Van Der Mark, P.; Ayres, D.L.; Darling, A.; Höhna, S.; Larget, B.; Liu, L.; Suchard, M.A.; Huelsenbeck, J.P. MrBayes 3.2: efficient Bayesian phylogenetic inference and model choice across a large model space. Syst. Biol. 2012, 61, 539-542.

38. Miller, M.A.; Pfeiffer, W.; Schwartz, T. The CIPRES science gateway: a community resource for phylogenetic analyses. In Proceedings of the Proceedings of the 2011 TeraGrid Conference: extreme digital discovery; 2011; pp. 1-8.

39. Rambaut, A.; Drummond, A.J. Tracer v1. 5 [http://beast. bio. ed. ac. uk/Tracer] 2009.

40. Huelsenbeck, J.P.; Ronquist, F.; Nielsen, R.; Bollback, J.P. Bayesian inference of phylogeny and its impact on evolutionary biology. Science (80-. ). 2001, 294, 2310-2314. 
41. Rambaut, A.; Drummond, A.J. FigTree v1. 4. 20122012.

42. Snyder, S.D. Phylogeny and paraphyly among tetrapod blood flukes (Digenea: Schistosomatidae and Spirorchiidae). Int. J. Parasitol. 2004, 34, 1385-1392.

43. Al-Zaidan, A.S.Y.; Kennedy, H.; Jones, D.A.; Al-Mohanna, S.Y. Role of microbial mats in Sulaibikhat Bay (Kuwait) mudflat food webs: evidence from $\delta 13 C$ analysis. Mar. Ecol. Prog. Ser. 2006, 308, 2736.

44. Bearup, A.J. A schistosomc larva from the marine snail Pyrazus australis as a cause of cercarial dermatitis in man. Med. J. Aust. 1955, 1, 955-960.

45. Grodhaus, G.; Keh, B. The marine, dermatitis-producing cercaria of Austrobilharzia variglandisin California (Trematoda: Schistosomatidae). J. Parasitol. 1958, 633-638.

46. Sindermann, C.J. Ecological studies of marine dermatitis-producing schistosome larvae in northern New England. Ecology 1960, 41, 678-684.

47. Pinto, H.A.; Pulido-Murillo, E.A.; de Melo, A.L.; Brant, S. V Putative new genera and species of avian schistosomes potentially involved in human cercarial dermatitis in the Americas, Europe and Africa. Acta Trop. 2017, 176, 415-420.

48. Hechinger, R.F.; Lafferty, K.D. Host diversity begets parasite diversity: bird final hosts and trematodes in snail intermediate hosts. Proc. R. Soc. B Biol. Sci. 2005, 272, 1059-1066.

49. Brant, S. V; Loker, E.S. Can specialized pathogens colonize distantly related hosts? Schistosome evolution as a case study. PLoS Pathog. 2005, 1, e38.

50. Blair, D.; Davis, G.M.; Wu, B. Evolutionary relationships between trematodes and snails emphasizing schistosomes and paragonimids. Parasitology 2001, 123, 229-243.

51. Miller Jr, H.M.; Northup, F.E. The seasonal infestation of Nassa obsoleta (Say) with larval trematodes. Biol. Bull. 1926, 50, 490-508.

52. Chu, G.; Cutress, C.E. Human dermatitis caused by marine organisms in Hawaii. In Proceedings of the Proceedings of the Hawaiian Academy of Science. 29th Annual Meeting (1953-54); 1954.

53. Szidat, L. Investigaciones sobre Cercaria chascomusi n. sp. Agente causal de una nueva enfermedad humana en la Argentina: La dermatitis de los bañistas de la laguna Chascomús. Bol Mus Argent Cienc Nat" Bernardino Rivadavia"1958, 18, 1-16.

54. ITO, J. Studies on the morphology and life cycle of Pseudobilharziella corvi Yamaguti, 1941 (Trematoda: Schistosomatidae). Japanese J. Med. Sci. Biol. 1960, 13, 53-58.

55. Karamian, M.; Aldhoun, J.A.; Maraghi, S.; Hatam, G.; Farhangmehr, B.; Sadjjadi, S.M. Parasitological and molecular study of the furcocercariae from Melanoides tuberculata as a probable agent of cercarial dermatitis. Parasitol. Res. 2011, 108, 955-962.

56. Leedom, W.S.; Short, R.B. Cercaria pomaceae sp. n., a dermatitis-producing schistosome cercaria from Pomacea paludosa, the Florida apple snail. J. Parasitol. 1981, 257-261.

57. Aldhoun, J.A.; Faltýnková, A.; Karvonen, A.; Horák, P. Schistosomes in the North: A unique finding from a prosobranch snail using molecular tools. Parasitol. Int. 2009, 58, 314-317. 
58. Horák, P.; Kolářová, L.; Adema, C.M. Biology of the schistosome genus Trichobilharzia. 2002.

59. Martorelli, S.R. Sobre una cercaria de la familia Schistosomatidae (Digenea) parásita de Chilina gibbosa Sowerby, 1841 en el lago Pellegrini, Provincia de Río Negro, República Argentina.Neotrópica 1984, 30, 97-106.

60. Braun, M. Zur Revision der Trematoden der Vögel II.Zentralblatt fur Bakteriol. Abth /1901, 29, 895897.

61. Cheatum, E.L. Dendritobilharzia anatinarum n. sp., a blood fluke from the mallard. J. Parasitol. 1941, $27,165-170$.

62. Leite, A.C.R.; Costa, H.M. de A.; Costa, J.O. Trichobilharzia jequitibaensis sp. n.(Trematoda, Schistosomatidae) in Cairina moschata domestica (Anatidae). Rev. Bras. Biol. 1978.

63. McLeod, J.A. Two new schistosomid trematodes from water-birds. J. Parasitol. 1937, 23, 456-466.

64. Ebbs, E.T.; Loker, E.S.; Davis, N.E.; Flores, V.; Veleizan, A.; Brant, S. V Schistosomes with wings: how host phylogeny and ecology shape the global distribution of Trichobilharzia querquedulae (Schistosomatidae). Int. J. Parasitol. 2016, 46, 669-677.

65. Flores, V.; Viozzi, G.; Casalins, L.; Loker, E.S.; Brant, S.V. A new schistosome (Digenea: Schistosomatidae) from the nasal tissue of South America black-necked swans, Cygnus melancoryphus(Anatidae) and the endemic pulmonate snail Chilina gibbosa. Zootaxa 2021, 4948, zootaxa-4948.

66. Kolářová, L.; Horák, P.; Skírnisson, K.; Marečková, H.; Doenhoff, M. Cercarial dermatitis, a neglected allergic disease. Clin. Rev. Allergy Immunol. 2013, 45, 63-74.

\section{Figures}




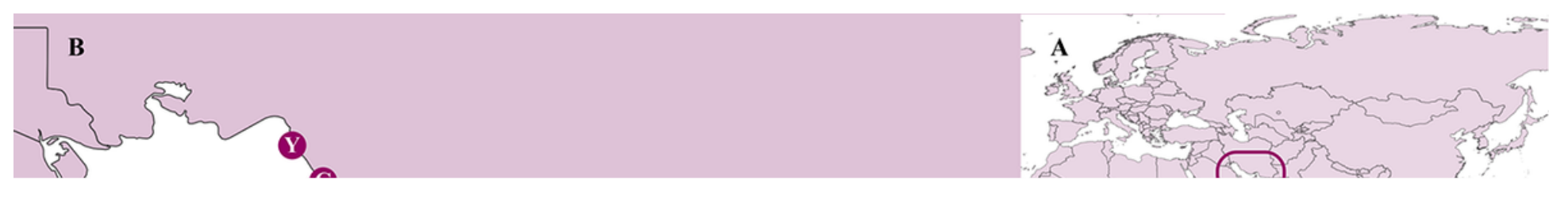

\section{Figure 1}

(A) Map - general view and (B) sampling localities along the Persian Gulf and the Gulf of Oman off Iran. Points correspond to the sampling localities. Abbreviations: A, Azini; D, Dargahan; G, Gevanesh; J, Jask; M, Geshm; S, Shif; T, Bandar Abbas; Y, Deylam; U, Bushehr. (C) Snail intermediate host Pirenella cingulata (Gmelin, 1791). (D) Cercaria collected from P. cingulata. Scale-bar $=100 \mu \mathrm{m}$

\section{Figure 2}

Bayesian analyses of the (A) $28 \mathrm{~S}$ rDNA and (B) $\operatorname{cox} 1$ datasets constructed using MrBayes v. 3.2.3 under the GTR $+1+\Gamma$ model of sequence evolution. Analyses were run for $10,000,000$ generation and $25 \%$ discarded as "burn-in". Posterior probability values are given above the branches; values. Nodes with $<0.95$ posterior probability support have been collapsed. Branch length scale-bar indicates number of substitutions per site. Newly-generated sequences are indicated in colour indicated red and bold. Hosts of origin of individual sequences are indicated after the specimen's host name. Branches in blue indicate schistosomes with marine life-cycle. Shaded areas and taxa outlined with doted lines reflect on the current taxonomic framework of the family and also given on the right. 


\section{Supplementary Files}

This is a list of supplementary files associated with this preprint. Click to download.

- Khosravietal.Suppl.1TABLEGenBanksequences2022.02.18.xIsx 